\title{
Clinical diagnosis and treatment of spinal cord injury without evidence of abnormality in children: a review
}

\author{
Jamal A. S. Alshorman, Yulong Wang, Fengzhao Zhu, Lian Zeng, Kaifang Chen, \\ Sheng Yao, Xirui Jing, Xiaodong Guo*
}

\begin{abstract}
Department of Orthopedics, Union hospital, Tongji Medical College, Huazhong University of Science and Technology, Wuhan, China
\end{abstract}

Received: 19 September 2020

Accepted: 09 October 2020

*Correspondence:

Dr. Xiaodong Guo,

E-mail: xiaodongguo@hust.edu.cn

Copyright: ( ) the author(s), publisher and licensee Medip Academy. This is an open-access article distributed under the terms of the Creative Commons Attribution Non-Commercial License, which permits unrestricted non-commercial use, distribution, and reproduction in any medium, provided the original work is properly cited.

\begin{abstract}
Spinal cord injury without radiological abnormality (SCIWORA) is a challenging circumstance in all age groups. Symptoms in some children of SCIWORA does not develop at the time of trauma. Different treatment methods (steroid therapy, immobilization, surgery) applied to treat SCIWORA, but with different prognosis. SCIWORA diagnosed when X-rays and computed tomography (CT) normal; however, initial magnetic resonance imaging (MRI) sometimes can be expected. Performing diffusion-weighted imaging (DWI) with early conventional MRI is a gold standard in the diagnosis of SCIWORA. Early MRI and DWI provides a quick diagnosis to facilitate recovery, ensure a superior clinical outcome, and choose a proper treatment method. Although it provides an accurate diagnosis, early immobilization with steroid therapy can present a good prognosis but not in all cases. Durotomy with duraplasty had a good outcome in adult patients, which might be helpful in children. This review explores the current and future methods of diagnosis and treatment of SCIWORA in children.
\end{abstract}

Keywords: SCIWORA, MRI, Laminectomy, Durotomy, Duraplasty

\section{INTRODUCTION}

Spinal cord injuries (SCI) are scarce in pediatric patients and represent less than $10 \%$ of total spinal cord injuries. Therefore, younger patients with SCI are more likely to develop SCIWORA due to the elasticity of the vertebral ligaments and immaturity of bony structures in the pediatric spine. ${ }^{1-3}$

Many articles on SCIWORA include when the neurological deficit appeared, when a magnetic resonance imaging (MRI) was performed, and the methods of treatment. However, performing an MRI on admission or within the first seven hours of injury can help in early diagnosis. ${ }^{4-8} \mathrm{~T} 1$ and T2-weighted MRIs of the spinal cord differentiate white from grey matter and identify macroscopic anatomical changes within the cord in a diseased or injured area. In pediatrics, various treatment methods have poor effects on SCIWORA; some authors advocate treating patients with immobilization and corticosteroid therapy followed by rehabilitation. ${ }^{9-14}$ The treatment of SCIWORA in children depends on supportive treatment and the prevention of secondary injuries, such as external immobilization to fulfill the patient's mobilization and rehabilitation. This review aims to explore the importance of MRI in the diagnosis of SCIWORA and investigates appropriate treatment methods that will produce a better clinical outcome and quick recovery.

\section{METHODS}

In this work, the management and diagnostic methods of SCIWORA in children were reviewed along with appropriate treatments (Figure 2). PubMed, google scholar, academia web, and other websites were used to 
select articles relevant to spinal cord injuries without fractures and dislocation in patients between infancy and $<18$ years old. Excluded articles included those with fractures and dislocation and those referring to patients over the age of 18. Initial research found SCI-related articles $(n=140)$; the inclusion criteria were then applied to find articles correlated to SCIWORA in children $(n=24)$ (Figure 1).

Inclusion criteria included infancy to less than 18 years old, trauma patients with spinal cord injury, no fractures or dislocations on the X-ray or CT scan and articles written in the English language.

Exclusion criteria excluded articles referring to adult patients, X-ray or CT showed abnormality and articles not written in the English language.

Patients data were analyzed using SPSS statistical software (version 22). Treatment methods were compared

along with the improvement in neurological symptoms. The $\mathrm{p}$ value was $<0.05$.

\section{RESULTS}

A detailed survey was performed and 24 articles were analyzed that included children with SCIWORA. There were 177 SCIWORA patients aged from infancy to $<18$ years old who fulfilled the inclusion criteria (Figure 1). While 119 patients showed an improvement in their symptoms, 58 did not change (Figure $3 \mathrm{~b}$ ).

Patient characteristics included the youngest patient was 12 months old and the oldest was <18; the gender split was $62.5 \%$ males and $37.5 \%$ females. The most common cause of trauma was an MVA ( $\mathrm{n}=59,33.33 \%)$ (Figure $3 d)$, followed by a fall $(n=47,26.55 \%)$, sport $(n=39$, $22.03 \%)$, and other mechanisms $(n=32,18.09 \%)$ (Table 1). The most injured regions were cervical, thoracic, and in a few cases, the lumbar region.

Imaging characteristics included the earliest MRI scan was performed on admission, while the latest was carried out on the fourteenth day from the onset of the injury. MRIs play a crucial role in revealing oedema, haemorrhage, and cystic cavities after the injury. Sixty cases showed a normal MRI without any abnormalities or pathological changes. However, using a conventional MRI with other techniques, like DWI, can show the appearance of abnormal signals or detect early signs of ischemia. ${ }^{5}$ The other cases showed oedema, contusion, hyperintensity signals, swelling, or haemorrhage after performing an initial MRI, as presented in Table 2.

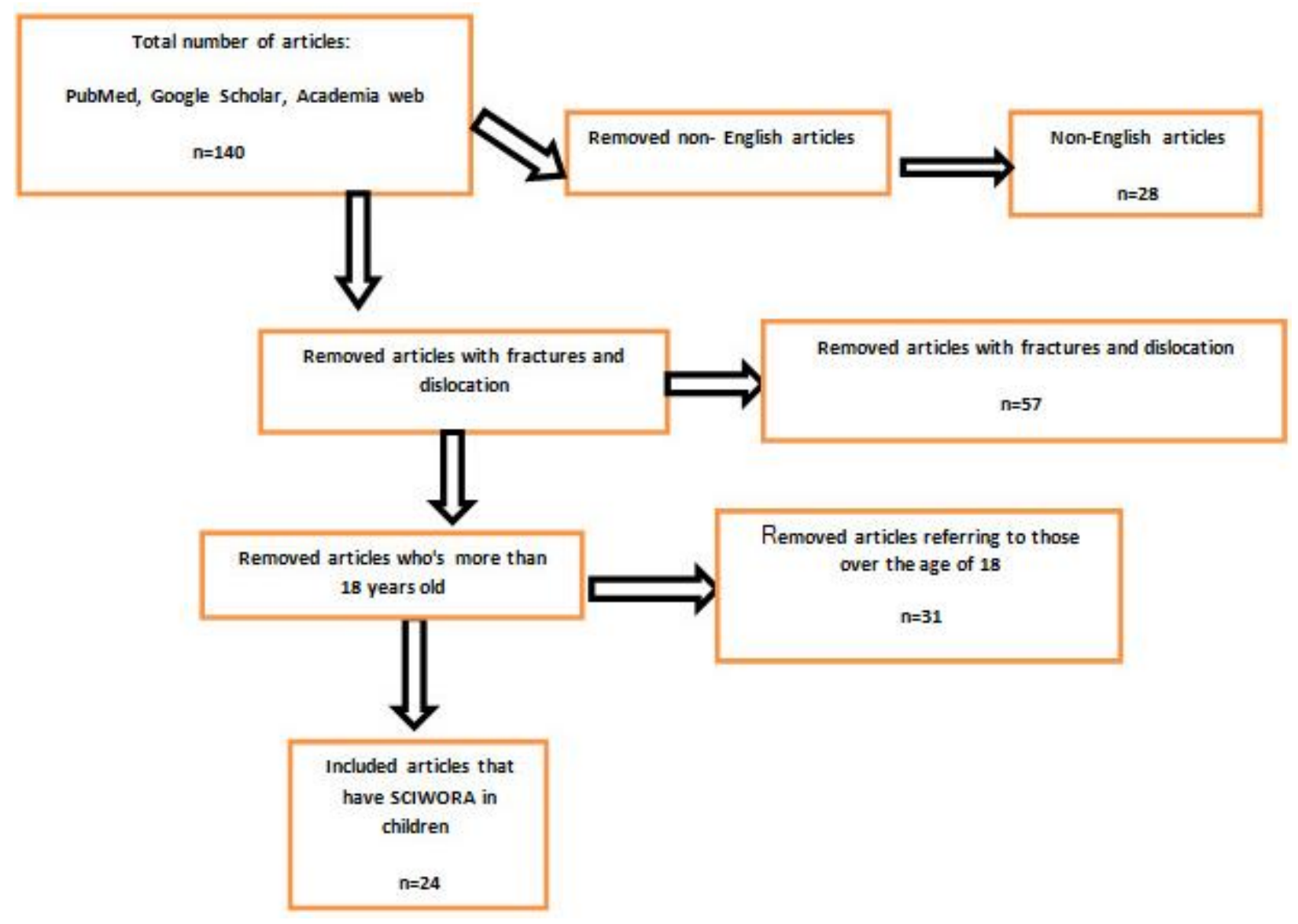

Figure 1: Inclusion criteria for article selection. 


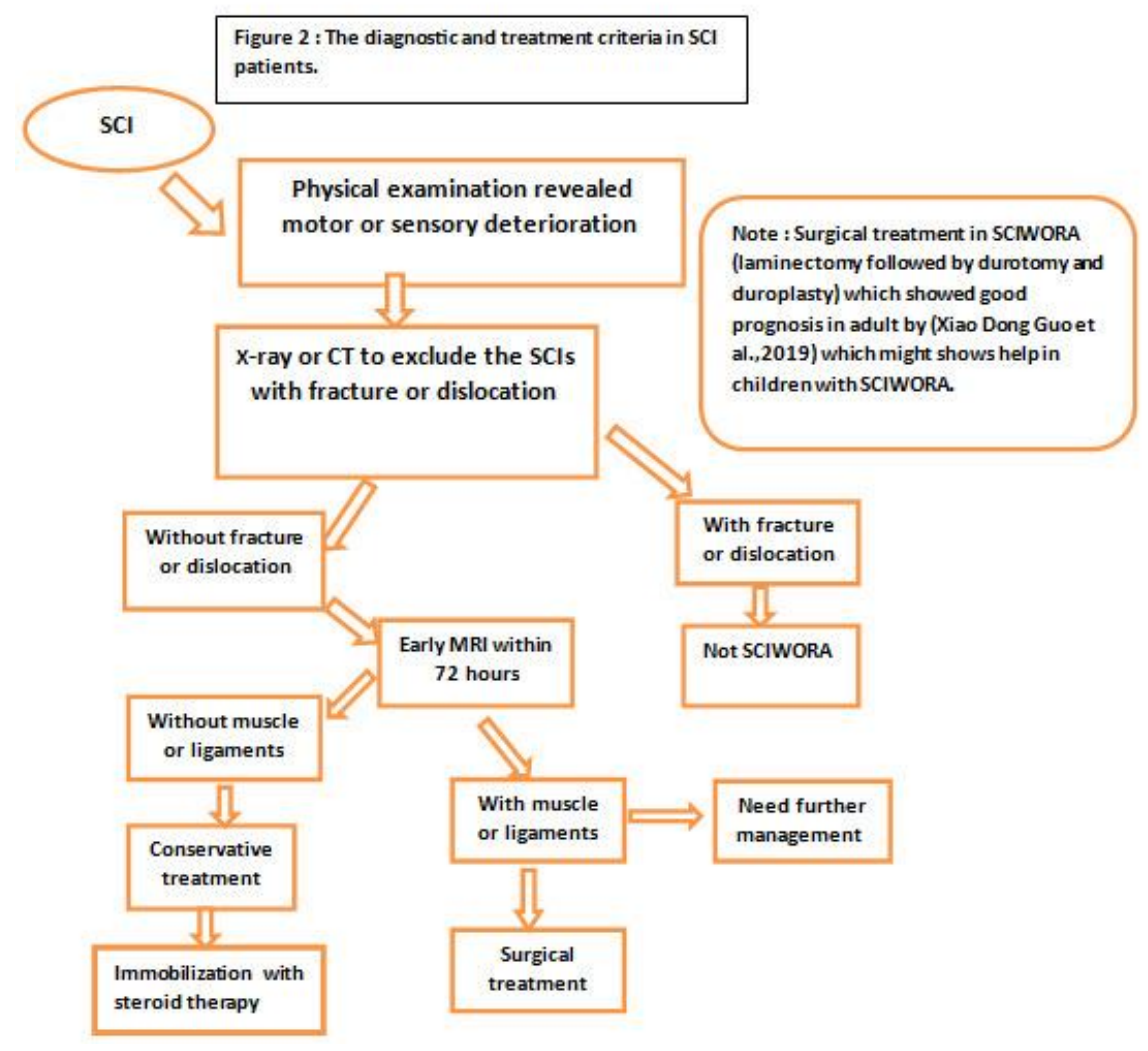

Figure 2: Diagnostic and treatment criteria in SCI patients. After exclusion of fractures and dislocation by X-rays and CTs, early MRI to detect the pathological changes and choose appropriate treatment method.

Table 1: Cases data.

\begin{tabular}{|c|c|c|c|c|c|c|c|c|c|}
\hline \multirow{2}{*}{ Author } & \multirow{2}{*}{$\begin{array}{l}\mathbf{N}, \text { Avg } \\
\text { age (year) }\end{array}$} & \multicolumn{2}{|c|}{ Sex } & \multicolumn{4}{|c|}{ Trauma mechanism } & \multirow{2}{*}{ Treatment } & \multirow{2}{*}{ Prognosis } \\
\hline & & $\mathbf{M}$ & $\mathbf{F}$ & Fall & MVA & Sport & Other & & \\
\hline $\begin{array}{l}\text { Bansal et al } \\
(2016)^{15}\end{array}$ & 1 case, 9 & 0 & 1 & 1 & 0 & 0 & 0 & $\begin{array}{l}\text { Immobilized in } \\
\text { pediatric cervical } \\
\text { collar, } \\
\text { corticosteroids }\end{array}$ & Good prognosis \\
\hline $\begin{array}{l}\text { Izma et al } \\
(2003)^{10}\end{array}$ & 3 cases, 4 & 2 & 1 & 0 & 3 & 0 & 0 & Immobilization & $\begin{array}{l}2 \text { cases showed good } \\
\text { prognosis; } 1 \text { case had } \\
\text { a bad outcome }\end{array}$ \\
\hline $\begin{array}{l}\text { Beck et al } \\
(2000)^{2}\end{array}$ & 1 case, 16 & 0 & 1 & 0 & 0 & 1 & 0 & $\begin{array}{l}\text { High dose } \\
\text { methylprednisolone } \\
30 \mathrm{mg} / \mathrm{kg}\end{array}$ & Complete recovery \\
\hline $\begin{array}{l}\text { Albuja et al } \\
(2017)^{5}\end{array}$ & $\begin{array}{l}2 \text { cases, } \\
14.5\end{array}$ & 0 & 2 & 0 & 0 & 0 & 2 & NS & $\begin{array}{l}1 \text { case became } \\
\text { paraplegic; } 2^{\text {nd }} \text { case } \\
\text { showed limited } \\
\text { improvement }\end{array}$ \\
\hline $\begin{array}{l}\text { Feldman et al } \\
(2008)^{16}\end{array}$ & $\begin{array}{l}5 \text { cases, } \\
6.1 \mathrm{~m}\end{array}$ & 0 & 5 & 0 & 0 & 0 & 5 & $\begin{array}{l}\text { Immobilization and } \\
\text { hospital course }\end{array}$ & $\begin{array}{l}1 \text { case became } \\
\text { normal; others had } \\
\text { poor prognosis }\end{array}$ \\
\hline $\begin{array}{l}\text { Liao et al } \\
(2005)^{6}\end{array}$ & 9 cases, 4 & 6 & 3 & 4 & 5 & 0 & 0 & $\begin{array}{l}\text { Immobilization, } \\
\text { steroids in } 7 \\
\text { patients }\end{array}$ & $\begin{array}{l}7 \text { patients showed } \\
\text { good prognosis; } 2 \\
\text { remained the same }\end{array}$ \\
\hline $\begin{array}{l}\text { Kim et al } \\
(2016)^{17}\end{array}$ & $\begin{array}{l}2 \text { cases, } \\
13.5\end{array}$ & 2 & 0 & 0 & 1 & 1 & 0 & $\begin{array}{l}\text { Immobilization, } \\
\text { methylprednisolone }\end{array}$ & $\begin{array}{l}\text { Paraplegic, complete } \\
\text { recovery }\end{array}$ \\
\hline $\begin{array}{l}\text { Klakeel et al } \\
(2015)^{12}\end{array}$ & 2 cases, 13 & 2 & 0 & 0 & 0 & 0 & 2 & Corticosteroids & $\begin{array}{l}1 \text { case had a poor } \\
\text { outcome; the other no } \\
\text { improvement }\end{array}$ \\
\hline
\end{tabular}




\begin{tabular}{|c|c|c|c|c|c|c|c|c|c|}
\hline \multirow{2}{*}{ Author } & \multirow{2}{*}{$\begin{array}{l}\mathbf{N}, \mathbf{A v g} \\
\text { age (year) }\end{array}$} & \multicolumn{2}{|l|}{ Sex } & \multicolumn{4}{|c|}{ Trauma mechanism } & \multirow{2}{*}{ Treatment } & \multirow{2}{*}{ Prognosis } \\
\hline & & $\mathbf{M}$ & $\mathbf{F}$ & Fall & MVA & Sport & Other & & \\
\hline $\begin{array}{l}\text { Sidram et al } \\
(2009)^{18}\end{array}$ & $\begin{array}{l}9 \text { cases, } \\
<12\end{array}$ & 7 & 2 & 6 & 2 & 0 & 1 & $\begin{array}{l}\text { External } \\
\text { immobilization, } \\
\text { methylprednisolone }\end{array}$ & $\begin{array}{l}7 \text { patents complete } \\
\text { recovery; } 2 \text { showed } \\
\text { partial recovery }\end{array}$ \\
\hline $\begin{array}{l}\text { Panagopoulos } \\
(2018)^{7}\end{array}$ & 1 case, 6 & 0 & 1 & 1 & 0 & 0 & 0 & Guilford-type brace & Full recovery \\
\hline $\begin{array}{l}\text { Kriss et al } \\
(1996)^{1}\end{array}$ & $\begin{array}{l}3 \text { cases, } \\
2.5 \mathrm{~m}\end{array}$ & 2 & 1 & 0 & 2 & 0 & 1 & $\begin{array}{l}\text { Conservative } \\
\text { treatment }\end{array}$ & $\begin{array}{l}2 \text { patients did not } \\
\text { recover; } 1 \text { had a good } \\
\text { outcome }\end{array}$ \\
\hline $\begin{array}{l}\text { Hon et al } \\
(2006)^{4}\end{array}$ & 1 case, 9 & 0 & 1 & 1 & 0 & 0 & 0 & Corticosteroids & No recovery \\
\hline $\begin{array}{l}\text { Mahajan et al } \\
(2013)^{19}\end{array}$ & $\begin{array}{l}69 \text { cases, } \\
<16\end{array}$ & 53 & 16 & 18 & 8 & 27 & 16 & $\begin{array}{l}\text { Immobilization and } \\
\text { corticosteroids }\end{array}$ & $\begin{array}{l}\text { Most of the patients } \\
\text { showed good } \\
\text { recovery }\end{array}$ \\
\hline $\begin{array}{l}\text { Kim et al } \\
(2008)^{11}\end{array}$ & 1 case, 1 & 0 & 1 & 1 & 0 & 0 & 0 & Neck collar & $\begin{array}{l}\text { After follow-up, } \\
\text { showed good } \\
\text { recovery, near normal }\end{array}$ \\
\hline $\begin{array}{l}\text { Kalra et al } \\
(2006)^{20}\end{array}$ & 1 case, 2.5 & 1 & 0 & 1 & 0 & 0 & 0 & $\begin{array}{l}\text { Proper } \\
\text { physiotherapy was } \\
\text { advised }\end{array}$ & Poor outcome \\
\hline $\begin{array}{l}\text { Koestner et al } \\
(2001)^{13}\end{array}$ & $\begin{array}{l}1 \text { case } \\
17 \mathrm{~m}\end{array}$ & 0 & 1 & 0 & 0 & 0 & 1 & Cervical collar & Poor outcome \\
\hline $\begin{array}{l}\text { Pang et al } \\
(1989)^{21}\end{array}$ & $\begin{array}{l}55 \text { cases, } \\
6 m-16\end{array}$ & 29 & 22 & 13 & 31 & 10 & 1 & $\begin{array}{l}\text { Patients initially } \\
\text { underwent } \\
\text { immobilization }\end{array}$ & $\begin{array}{l}33 \text { children with mild } \\
\text { or moderate injuries } \\
\text { showed sufficient } \\
\text { improvement; } 22 \\
\text { children with poor } \\
\text { outcome }\end{array}$ \\
\hline $\begin{array}{l}\text { Ergun et al } \\
(2003)^{22}\end{array}$ & 1 case, 12 & 0 & 1 & 0 & 0 & 0 & 1 & $\begin{array}{l}\text { Steroids for } 6 \\
\text { weeks followed by } \\
\text { oral prednisolone }\end{array}$ & Good recovery \\
\hline $\begin{array}{l}\text { Silman et al } \\
(2008)^{23}\end{array}$ & $\begin{array}{l}1 \text { case, } \\
11 \mathrm{~m}\end{array}$ & 1 & 0 & 0 & 1 & 0 & 0 & $\begin{array}{l}\text { Conservative } \\
\text { treatments }\end{array}$ & $\begin{array}{l}\text { Patient remained } \\
\text { paraplegic. }\end{array}$ \\
\hline $\begin{array}{l}\text { Matsumura } \\
\text { et al }(1990)^{14}\end{array}$ & 1 case, 3 & 0 & 1 & 0 & 1 & 0 & 0 & $\begin{array}{l}\text { Halo vest for } 8 \\
\text { weeks }\end{array}$ & No recovery \\
\hline $\begin{array}{l}\text { Ayaz et al } \\
(2013)^{24}\end{array}$ & 1 case, 3.5 & 1 & 0 & 0 & 1 & 0 & 0 & $\begin{array}{l}\text { Therapeutic } \\
\text { exercises and } \\
\text { electrical muscle } \\
\text { stimulation }\end{array}$ & Poor recovery \\
\hline $\begin{array}{l}\text { Sesmat et al } \\
(2018)^{25}\end{array}$ & $\begin{array}{l}3 \text { cases, } \\
2.3\end{array}$ & NS & NS & 0 & 3 & 0 & 0 & NS & No recovery \\
\hline $\begin{array}{l}\text { Liang et al } \\
(2019)^{26}\end{array}$ & $\begin{array}{l}3 \text { cases, } \\
6.33\end{array}$ & 1 & 2 & 1 & 0 & 0 & 2 & $\begin{array}{l}\text { Corticosteroids, } \\
\text { operation }\end{array}$ & Poor prognosis \\
\hline $\begin{array}{l}\text { Nagasawa et } \\
\text { al }(2017)^{8}\end{array}$ & 1 case, 13 & 0 & 1 & 0 & 1 & 0 & 0 & $\begin{array}{l}\text { Bed rest, neck } \\
\text { collar }\end{array}$ & Complete recovery \\
\hline
\end{tabular}

$\mathrm{F}=$ female; $\mathrm{M}=$ male; $\mathrm{MVA}=$ motor vehicle accidents; $\mathrm{NS}=$ Not stated; $\mathrm{n}=$ number of SCIWORA cases.

\section{Relationship between the treatment method and prognosis}

Fourteen articles reported using immobilization methods to treat SCIWORA, while only 11 articles highlighted the use of corticosteroids; one article focused on the use of corticosteroids with an operation, but this demonstrated a poor prognosis. Combining both immobilization and corticosteroids into one integrated method to treat the patients showed a better clinical outcome than using only immobilization or corticosteroids. ${ }^{6,12,15,17-19}$
Two patients received physiotherapy and three patients had an operation and were given steroids, but they did not show any improvements. Five patients received steroid therapy and two of them demonstrated improved symptoms. Sixty-four patients had immobilization only and 39/64 showed an improvement in symptoms. The use of steroids with immobilization was the best treatment method as this showed improvements in 74/98 patients (Figure 3c). Four patients were non-stated (Figure 3a). 

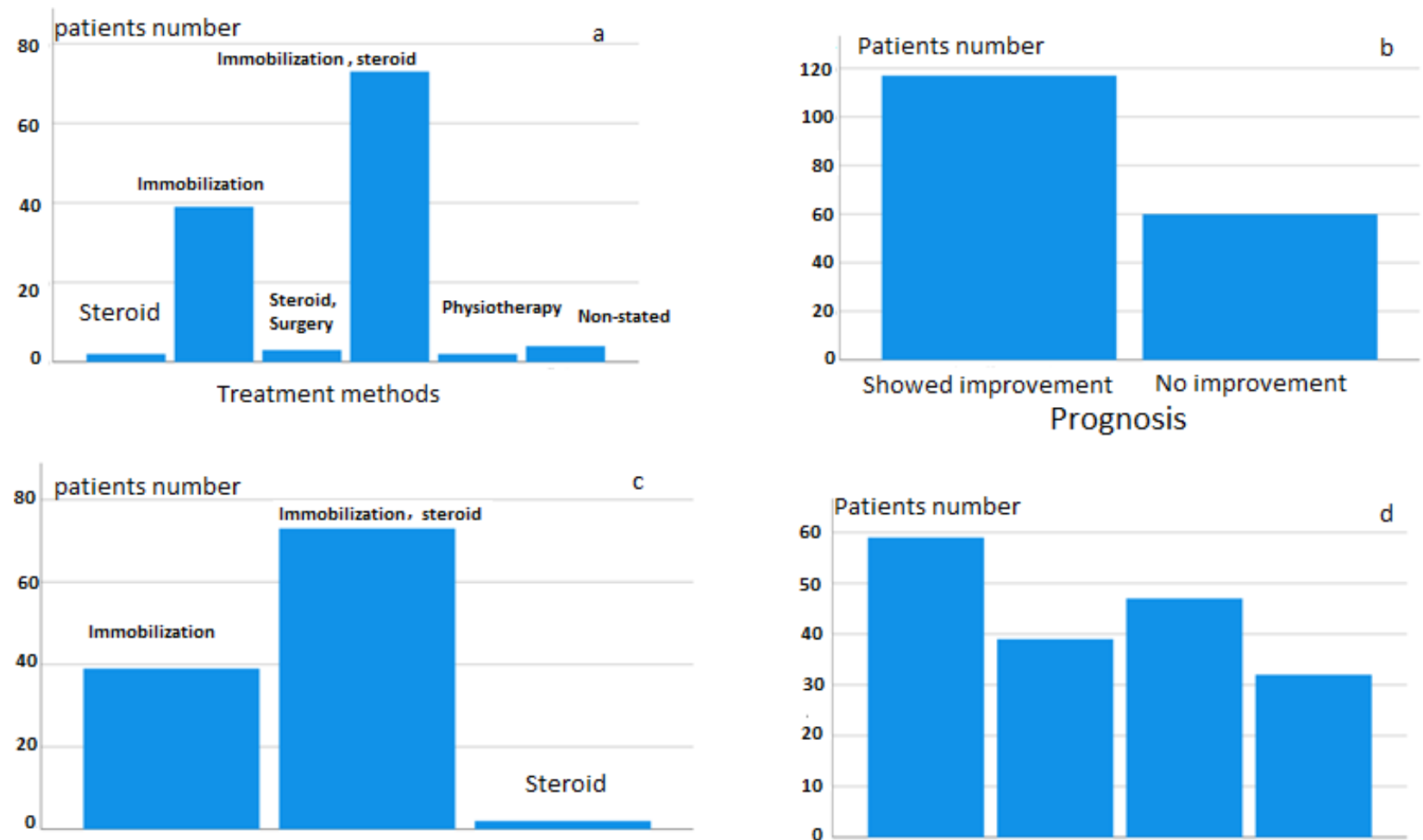

Prognosis with different treatment

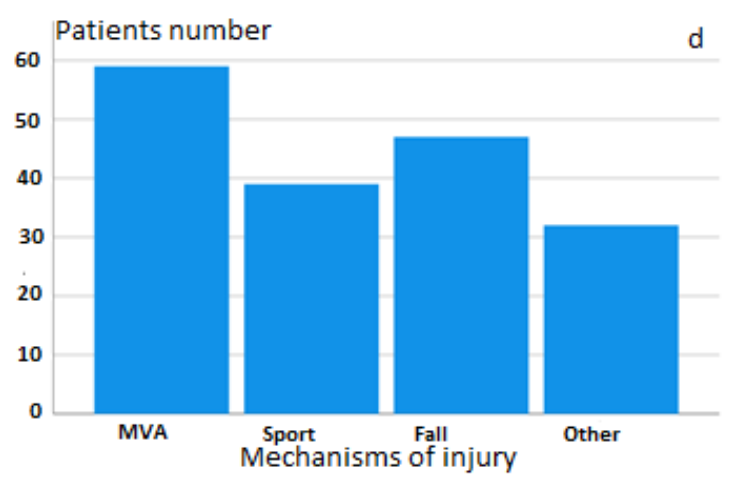

Figure 3: Statistical analysis of all patients included in this review, (a) patient numbers according to the treatment method, (b) patient numbers with improvement in neurological symptoms, (c) neurological improvement after treatment, (d) cause of injury.

Table 2: Images and appearance on MRI.

\begin{tabular}{|c|c|c|c|c|c|}
\hline Study & Level & $\begin{array}{l}\text { Time of MRI } \\
\text { (days) }\end{array}$ & Appearance on MRI & X-ray & CT \\
\hline Bansal et al (2016) $)^{15}$ & Cervical & $\mathrm{NS}$ & Non-hemorrhagic cord edema & NS & Yes \\
\hline Izma et al $(2003)^{10}$ & $\begin{array}{l}\text { Thoracic- } \\
\text { cervical }\end{array}$ & 6-9 days & $\begin{array}{l}\text { Epidural hematoma } \\
\text { Atrophic spinal cord } \\
\text { Unilateral swelling }\end{array}$ & Yes & Yes \\
\hline Beck et al. $(2000)^{2}$ & Cervical & $\begin{array}{l}\text { Next morning } \\
\text { after admission }\end{array}$ & Minimal edema and swelling & Yes & NS \\
\hline Albuja et al $(2017)^{5}$ & $\begin{array}{l}\text { Thoracic } \\
\text { Thoracic- } \\
\text { lumber }\end{array}$ & Admission & Hyperintensity & Yes & NS \\
\hline Feldman et al $(2008)^{16}$ & Cervical & $2-5$ & $\begin{array}{l}\text { Right posterior medulla } \\
\text { hemorrhage, cord swelling }\end{array}$ & Yes & Yes \\
\hline Liao et al $(2005)^{6}$ & $\begin{array}{l}\text { Thoracic- } \\
\text { cervical }\end{array}$ & 3 hours-14 & $\begin{array}{l}2 \text { spinal cord transection cases } \\
1 \text { edema case } \\
3 \text { contusion with hematomyelia } \\
\text { cases, } 3 \text { normal cases }\end{array}$ & Yes & Yes \\
\hline Kim et al $(2016)^{17}$ & $\begin{array}{l}\text { Thoracic, } \\
\text { cervical }\end{array}$ & NS & $\begin{array}{l}\text { Contusion or hematoma } \\
\text { Focal central disc herniation }\end{array}$ & Yes & Yes \\
\hline Klakeel et al (2015) & Thoracic & NS & $\begin{array}{l}\text { Hyperintensity ischemic or } \\
\text { demyelinating process }\end{array}$ & NS & Yes \\
\hline Sidram et al (2009) & $\begin{array}{l}6 \text { cervical } \\
3 \text { thoracic }\end{array}$ & NS & $\begin{array}{l}3 \text { normal cases } \\
1 \text { contusion case } \\
5 \text { edema cases }\end{array}$ & Yes & Yes \\
\hline Panagopoulos $(2018)^{7}$ & Cervical & Admission & Abnormal signal intensity & Yes & Yes \\
\hline Kriss et al $(1996)^{1}$ & Cervical & NS & Abnormal signal & Yes & Yes \\
\hline Hon et al $(2006)^{4}$ & Thoracic & Admission & Hyperintensity with contusion & NS & Yes \\
\hline
\end{tabular}




\begin{tabular}{|c|c|c|c|c|c|}
\hline Study & Level & $\begin{array}{l}\text { Time of MRI } \\
\text { (days) }\end{array}$ & Appearance on MRI & X-ray & CT \\
\hline Mahajan et al (2013) ${ }^{19}$ & Cervical & NS & $\begin{array}{l}54 \text { normal cases } \\
15 \text { abnormal signal cases }\end{array}$ & Yes & Yes \\
\hline Kim et al (2008) ${ }^{11}$ & Cervical & 7 days & High-intensity signal & Yes & Yes \\
\hline Kalra et al $(2006)^{20}$ & Cervical & NS & High-intensity signal & Yes & Yes \\
\hline Koestner et al (2001) $)^{13}$ & Cervical & 14 hours & Cord edema & Yes & Yes \\
\hline Pang et al $(1989)^{21}$ & $\begin{array}{l}43 \text { cervical } \\
12 \text { thoracic }\end{array}$ & NS & NS & Yes & Yes \\
\hline Ergun et al $(2003)^{22}$ & Cervical & 2 & Hyperintensity lesion & Yes & NS \\
\hline Silman et al (2008) ${ }^{23}$ & $\begin{array}{l}\text { Thoracic- } \\
\text { cervical }\end{array}$ & NS & Contusion and hemorrhage & NS & Yes \\
\hline Matsumura et al (1990) ${ }^{14}$ & $\begin{array}{l}\text { Thoracic- } \\
\text { cervical }\end{array}$ & NS & Abnormal intensity & Yes & NS \\
\hline Ayaz et al $(2013)^{24}$ & Thoracic & $\begin{array}{l}\text { Next morning } \\
\text { after admission }\end{array}$ & Unremarkable & Yes & Yes \\
\hline Liang et al $(2019)^{26}$ & $\begin{array}{l}\text { Thoracic- } \\
\text { lumber }\end{array}$ & 3 days after injury & $\begin{array}{l}\text { Contusion and laceration, } \mathrm{T} 2 \\
\text { hyperintensity }\end{array}$ & NS & Yes \\
\hline Nagasawa et al $(2017)^{8}$ & Cervical & Admission & No significant spinal cord lesion & NS & Yes \\
\hline Sesmat et al (2018) ${ }^{25}$ & $\begin{array}{l}2 \text { thoracic- } \\
\text { cervical } \\
1 \text { cervical }\end{array}$ & NS & $\begin{array}{l}2 \text { contusion cases } \\
1 \text { high-intensity signal case }\end{array}$ & Yes & Yes \\
\hline
\end{tabular}

$\mathrm{CT}=$ Computed tomography; MRI=Magnetic resonance image; NS=Not stated.

\section{DISCUSSION}

Pang and Wilberger discovered SCIWORA in 1982 and prescribed it as a spinal cord injury with no evidence of fracture or instability on an X-ray or CT scan. ${ }^{28}$ It is called real SCIWORA if the evidence is undetectable on an MRI. ${ }^{30}$ Pang and Wilberger described the mechanisms of neural damage in SCIWORA and suggested that flexion force affects the paediatric spinal cord more than extension force. ${ }^{28}$ Some cases of SCIWORA caused by flexion-extension forces can cause temporary occlusion of the vertebral arteries and end with infarction. ${ }^{22,29}$

According to the collected articles, the cervical region was the most commonly affected area because of muscle weakness and inadequate ossification of the structural components of spinal segments, which increase spine flexibility. ${ }^{23}$ Another reason was that the size of the head is greater than the rest of the body. ${ }^{25}$ SCIWORA in the upper neck region is more prevalent in young children who are less than eight years old because the neck is more vulnerable to flexion force, while it becomes more resistant to the possibility of similar injuries after the age of nine. ${ }^{24}$

Pang suggested that the unique features of the paediatric spine increase the risk of SCIWORA. In children who are <ten years old, the uncinate processes are absent, in addition to the end plate's hypervascular growth zone. ${ }^{27}$ The unique elasticity of children's spines, such as increased flexibility, muscle weakness, and incomplete ossification of bony components, immensely increase the risk of SCIWORA in children. ${ }^{26}$ Paediatric SCIWORA requires exceptional management because of its dynamic nature, its development during the child's life, and anatomical discrepancies.

The prediction accuracy in this review covers the significance of delayed-onset follow-up after SCIWORA. This should be considered thoroughly, primarily due to the variations in each case. This review revealed that cases can develop clinical symptoms within minutes of injury or up to a few days later. This is because of rising intraspinal pressure that happens around 30 minutes after the injury and remains elevated up to seven days, while oedema increases in the first three days after the injury and continues over the next several days. ${ }^{9,39}$ It is vitally important to conduct an MRI and DWI as soon as possible to determine the pathological changes in the spinal cord. It should also be noted that acute deterioration is the most common type of neurological deterioration among paediatric patients with SCIWORA, and it appears temporarily within the first hours of injury. A DWI has some advantages in determining the ischemic changes in the spinal cord.

The literature reported 60 cases of SCIWORA in children without signal abnormalities on an MRI (i.e., real SCIWORA). Even with advanced MRI technology, the healthy appearance of neuroimaging remains a clinical episode in children with SCIWORA. ${ }^{20}$ Nevertheless, MRI has improved the ability to diagnose patients with SCIWORA by enabling the visualization of pathological spinal changes.

Diffusion-weighted MRI is more sensitive if the cause of SCIWORA is an arteriovenous malformation (AVM). ${ }^{5,18}$ However, clinical presentations of spinal cord AVMs can include progressive myelopathy or acute haemorrhage, 
such as fistulous AVMs, which are more likely to develop progressive myelopathy that can only be detected by MRI. MRI is very appropriate for the diagnosis of nidus in AVM associated with an increased risk of haemorrhage as it estimates the compressed cord and approves the intramedullary AVMs. ${ }^{31}$ Mulcahey et al examined the accuracy of DWI and concluded that it is more sensitive in detecting cord abnormality, which helps in early and accurate diagnosis, aids in deciding on appropriate treatment, and leads to a positive long-term prognosis. $^{33}$

After a few weeks, some cases showed a clinical condition that appeared as ascending myelopathy, $\geq$ four vertebral levels above the initial injury. ${ }^{32}$ However, some cases showed severe atrophy of the spine after one month of injury. An MRI detected spine abnormalities in some cases, such as cord oedema, contusion, hyperintensity signals, swelling, or haemorrhage. This illustrates the pathophysiology and main features of SCIWORA. The patients who underwent early and appropriate management showed an improvement in their neurological symptoms, which enhanced the probability of neurological recovery and reduced complications. . $^{2,5,7,8,13,16,24}$

MVAs are the most common causes of injury, followed by falls, sports, and other mechanisms (abuse, minor trauma, sudden onset). An excess of sports injuries occurred in adolescents, whereas MVA-related injuries were more common in toddlers. Hence, immobilization was essential to approximate neutral spine alignment in paediatric patients. Most of the cases treated with immobilization and steroid therapy showed a complete improvement as complete recovery can happen after mild or moderate lesions. Some cases showed no symptom improvements, and they remained paralyzed. Treatment outcomes in children with SCIWORA depend on the severity of the injury. For instance, a complete injury with severe lesions will not recover.

The variation of clinical outcomes in SCIWORA depends on the severity of the injury, while the importance of the initial neurological status is considered as a leading prognostic factor for a good outcome. ${ }^{21}$ The best recovery scenarios are expected with patients who have oedema or a cord without contusion or haemorrhage; unfortunately, the worst could be a haemorrhage around the cord.

In adults, many studies suggest the use of posterior laminectomy followed by durotomy with duraplasty, which is an effective method of decreasing intraspinal pressure and improving blood circulation at the swollen cord. ${ }^{34-37}$ Decreasing the pressure at the injury site helps to increase the blood flow, avoid further injury, which can relive cord oedema, and prevent the progress of spinal cord compartment syndrome. Therefore, treating the compartment syndrome depends on opening all the structures to reduce the pressure at the injury site. Muscle or ligament disruption can only appear on an MRI, which also increases the pressure at the injury site. Furthermore, increasing motor evoked potential at or below the injury site can predict the increase in spinal cord perfusion pressure (SCPP) and play a role in the assessment of injury severity. ${ }^{3}$

SCIWORA is diagnosed when X-rays and CTs are normal, while MRIs check the severity of the injury as to whether there are ligament and muscle disruption or not. ${ }^{2}$ If there is no tissue disruption, immobilization and corticosteroids can be a good treatment option as this method improved the symptoms in $23 / 26$ cases. ${ }^{6,15-18}$ Laminectomy followed by durotomy with duraplasty is recommended as a choice of treatment when a ligament or muscle is injured as this can decompress the dura against the swollen cord. The curative effect is still hard to judge after surgery in children, but it improves the prognosis in adults.

Twenty-four patients showed no improvement after immobilization with steroid therapy. To treat severe injury, surgical intervention can reduce intraspinal pressure. Dura is the major cause of spine compression in severe injury, so dural decompression and duraplasty can reduce intraspinal pressure and allow the perfusion pressure to be controlled with $<60 \mathrm{mmgH}$ to avoid secondary injury. ${ }^{40}$ Zhu et al performed early durotomy with duraplasty in adult patients and showed significant improvements. $^{54}$ Therefore, hypothesize that this procedure can achieve improvement in children who are severely injured. When starting treatment, the supine position, either operatively or conservatively, can increase the pressure at the injury site and potentially cause secondary injury; the lateral position will avoid increasing pressure. ${ }^{38}$

Finally, this review has a few limitations, such as the lack of a high standard study that provides sufficient information about MRI findings. Additionally, there was a lack of reports on SCIWORA and the exact method to diagnose or treat patients with positive long-term outcomes. Unfortunately, a lack of such critical details, especially regarding the injury severity of SCIWORA (acute, subacute, or chronic), generated another limitation.

\section{CONCLUSION}

Early and appropriate management would increase the efficiency of the healthcare system and bring efforts to fruition. A conventional MRI does not exclude SCIWORA, but using another technique, such as DWI can include it. After confirming injury severity, acute and subacute injuries can be treated conservatively while severe injury needs careful management for symptoms to improve. Surgical intervention may be required if the patient shows ligamentous instability or deformity. 
Funding: National Natural Science Foundation of China Conflict of interest: None declared

Ethical approval: Not required

\section{REFERENCES}

1. Kriss VM, Kriss TC. SCIWORA (Spinal cord injury without radiographic abnormality) in infants and children. Clin Pediatr (Phila). 1996;35(3):119-24.

2. Beck A, Gebhard F, Kinzl L, Rüter A, Hartwig E. Spinal cord injury without radiographic abnormalities in children and adolescents: A case report of a severe cervical spine lesion and review of the literature. Knee Surg Sports Traumatol Arthrosc. 2000;8(3):186-9.

3. Werndle MC, Saadoun S, Phang I, Czosnyka M, Varsos GV, Czosnyka ZH et al. Monitoring of spinal cord perfusion pressure in acute spinal cord injury: Initial findings of the injured spinal cord pressure evaluation study. Crit Care Med. 2014;42(3):646-55.

4. Hon KE, Chan SJ, Ng BK, Chu WC. Spinal cord injury without radiographic abnormality (SCIWORA): A mere $50-\mathrm{cm}$ fall that matters. Injury Extra. 2006;37(10):364-70.

5. Albuja AC, Qaiser S, Lightner DD, Raslau FD, Zafar MS, Bernard PA, et al. Surfer's myelopathy without surfing: a report of two pediatric patients. Spinal Cord Ser Cases. 2017;3(1):17008.

6. Liao CC, Lui TN, Chen LR, Chuang CC, Huang YC. Spinal cord injury without radiological abnormality in preschool-aged children: Correlation of magnetic resonance imaging findings with neurological outcomes. J Neurosurg. 2005;103(1):17-23.

7. Panagopoulos D. A case of SCIWORA with uncommon combination of neurological and imaging findings. EC Paediatr. 2018;6:498-506.

8. Nagasawa H, Ishikawa K, Takahashi R, Takeuchi I, Jitsuiki K, Ohsaka $\mathrm{H}$ et al. A case of real spinal cord injury without radiologic abnormality in a pediatric patient with spinal cord concussion. Spinal Cord Ser Cases 2017;3(1):17051.

9. Grassner L, Grillhösl A, Christoph J, Griessenauer CT, Bühren V, Strowitzki M et al. Spinal meninges and their role in spinal cord injury: A neuroanatomical review. J Neurotr. 2018;403-10.

10. Izma MK, Zulkharnain I, Ramli B, Muhamad AR, Harwant S. Spinal cord injury without radiological abnormality (SCIWORA). Med J Malaysia. 2003;58(1):105-10.

11. Kim SH, Yoon SH, Cho KH, Kim SH. Spinal cord injury without radiological abnormality in an infant with delayed presentation of symptoms after a minor injury. Spine (Phila Pa 1976). 2008;33(21):E792-E4.

12. Klakeel M, Thompson J, Srinivasan R, McDonald F. Anterior spinal cord syndrome of unknown etiology. Proc (Bayl Univ Med Cent). 2015;28(1):85-7.

13. Koestner AJ, Hoak SJ. Spinal cord injury without radiographic abnormality (SCIWORA) in children. J Trauma Nurs. 2001;8(4):101-8.
14. Matsumura A, Meguro K, Tsurushima H, Kikuchi Y, Wada M, Nakata Y. Magnetic resonance imaging of spinal cord injury without radiologic abnormality. Surg Neurol. 1990;33(4):281-3.

15. Bansal KR, Chandanwale AS. Spinal cord injury without radiological abnormality in an 8-month-old female child: A case report. J Orthop Case Rep. 2016;6(1):8-10.

16. Feldman KW, Avellino AM, Sugar NF, Ellenbogen RG. Cervical spinal cord injury in abused children. Pediatr Emerg Care. 2008;24(4):222-7.

17. Kim C, Vassilyadi M, Forbes JK, Moroz NWP, Camacho A, Moroz PJ. Traumatic spinal injuries in children at a single level 1 pediatric trauma center: Report of a 23-year experience. Can J Surg. 2016;59(3):205-12.

18. Sidram V, Tripathy P, Ghorai SP, Ghosh SN. Spinal cord injury without radiographic abnormality (SCIWORA) in children: A Kolkata experience. Indian J Neurotrauma. 2009;6(2):133-6.

19. Mahajan P, Jaffe DM, Olsen CS, Leonard JR, Nigrovic LE, Rogers AJ et al. Spinal cord injury without radiologic abnormality in children imaged with magnetic resonance imaging. J Trauma Acute Care Surg. 2013;75(5):843-7.

20. Kalra V, Gulati S, Kamate M, Garg A. SCIWORAspinal cord injury without radiological abnormality. Indian J Pediatr. 2006;73(9):829-31.

21. Pang D, Pollack IF. Spinal cord injury without radiographic abnormality in children-The SCIWORA syndrome. J Trauma Acute Care Surg. 1989;29(5):654-64.

22. Ergun A, Oder W. Pediatric care report of spinal cord injury without radiographic abnormality (SCIWORA): Case report and literature review. Spinal Cord. 2003;41(4):249-53.

23. Silman E, Langdorf MI, Rudkin S, Lotfipour S. Images in emergency medicine: Pediatric spinal cord injury without radiographic abnormality. West J Emerg Med. 2008;9(2):124.

24. Ayaz SB, Gill ZA, Matee S, Khan AA. Spinal cord injury without radiographic abnormalities (SCIWORA) in a preschool child: A case report. J Postgrad Med Inst. 2014;28(2):228-30.

25. Sesmat H, Hayoun T, Bonnet J, Poli-Mérol M, Bourelle S. Spinal cord injury without radiographic abnormality (SCIWORA): About 3 cases and review of the literature. Biomed J Sci Tech Res. 2018;8(1):6208-11.

26. Liang QC, Yang B, Song YH, Gao PP, Xia ZY, Bao N. Real spinal cord injury without radiologic abnormality in pediatric patient with tight filum terminale following minor trauma: A case report. BMC Pediatr. 2019;19(1):513.

27. Pang D. Spinal cord injury without radiologic abnormality in children, 2 decades later. Neurosurgery. 2004;55(6):1325-43.

28. Pang D, Wilberger JE. Spinal cord injury without radiographic abnormalities in children. J Neurosurg. 1982;57(1):114-29. 
29. AbdelRazek MA, Mowla A, Farooq S, Silvestri N, Sawyer R, Wolfe G. Fibrocartilaginous embolism: A comprehensive review of an under-studied cause of spinal cord infarction and proposed diagnostic criteria. J Spinal Cord Med. 2016;39(2):146-54.

30. Dreizin D, Kim W, Kim JS, Boscak AR, Bodanapally UK, Munera $F$ et al. Will the real SCIWORA please stand up? Exploring clinicoradiologic mismatch in closed spinal cord injuries. Am J Roentgenol. 2015;205(4):853-60.

31. Lee YJ, Terbrugge KG, Saliou G, Krings T. Clinical features and outcomes of spinal cord arteriovenous malformations. Stroke. 2014;45(9):2606-12.

32. Cao JM, Zhang JT, Yang DL, Yang YP, Xia HH, Yang L. Imaging factors that distinguish between patients with asymptomatic and symptomatic cervical spondylotic myelopathy with mild to moderate cervical spinal cord compression. Medical science monitor: Int Med J Exp Cli Res. 2017;23:4901-8.

33. Mulcahey MJ, Samdani AF, Gaughan JP, Barakat N, Faro S, Shah $P$ et al. Diagnostic accuracy of diffusion tensor imaging for pediatric cervical spinal cord injury. Spinal Cord. 2013;51(7):532-7.

34. Telemacque D, Zhu F, Chen K, Chen L, Ren Z, Yao $\mathrm{S}$ et al. Method of decompression by durotomy and duroplasty for cervical spinal cord injury in patients without fracture or dislocation. J Neurorestoratol. 2018;6(1):158-64.

35. Qu YZ, Guo XD. Durotomy and dural grafting to treat lower cervical spine injuries with extensive spinal cord edema. Neural Regen Res. 2015;10(12):1969-70.
36. Xie J, Deng X, Feng Y, Cao N, Zhang X, Fang F et al. Early intradural microsurgery improves neurological recovery of acute spinal cord injury: A study of 87 cases. J Neurorestoratol. 2018;6(1):1527.

37. Zhu F, Yao S, Ren Z, Telemacque D, Qu Y, Chen K et al. Early durotomy with duroplasty for severe adult spinal cord injury without radiographic abnormality: A novel concept and method of surgical decompression. Eur Spine J. 2019;28(10):2275-82.

38. Tykocki T, Poniatowski Ł, Czyż M, Koziara M, Wynne-Jones $\mathrm{G}$ et al. Intraspinal pressure monitoring and extensive duroplasty in the acute phase of traumatic spinal cord injury: A systematic review. World Neurosurg. 2017;105:145-52.

39. Khaing ZZ, Cates LN, Fischedick AE, McClintic AM, Mourad PD, Hofstetter CP et al. Temporal and spatial evolution of raised intraspinal pressure after traumatic spinal cord injury. J Neurotrauma. 2017;34(3):645-51.

40. Phang I, Werndle MC, Saadoun S, Varsos G, Czosnyka M, Zoumprouli A et al. Expansion duroplasty improves intraspinal pressure, spinal cord perfusion pressure, and vascular pressure reactivity index in patients with traumatic spinal cord injury: Injured spinal cord pressure evaluation study. $\mathrm{J}$ Neurotrauma. 2015;32(12):865-74.

Cite this article as: Alshorman JAS, Wang Y, Zhu F, Zeng L, Chen K, Yao S, et al. Clinical diagnosis and treatment of spinal cord injury without evidence of abnormality in children: a review. Int Surg J 2020;7:3847-55. 